\title{
The role of small scale enterprises in poverty reduction in rural areas of Sokoto State
}

\author{
Sirajo Abubakar Ibrahim, Zayyanu Ladan \\ Department of Geography, Shehu Shagari College of Education, Sokoto, Sokoto State, Nigeria
}

\begin{abstract}
Poverty reduction is a major goal and issue for many international organizations such as the United Nations and the World Bank. The World Bank estimated 1.29 billion people were living in absolute poverty in 2008 . This is more obvious with the regard to Nigeria where it was estimated about $70 \%$ (2010) of the population are living below poverty line. Similarly, the National Bureau of Statistics (NBS) recently released the figure in 2013., which indicate Sokoto state as having highest incidence of poverty, with $81.2 \%$ poverty rate. The pressure of poverty and the absence of any other income earning activity during the dry season force the people in these area of the North Western part of Sokoto on Migration after every raining season across the country, in order to sustain their livelihood. This paper is of the opinion that rural dwellers can be self reliant within their locality by utilizing the available resources as well as establishing some new business ideas for small scale business as a strategy in poverty reduction and controlling high migration rate. Similarly the paper recommend among others, the effective enlightenment awareness and motivation on the role of boosting the economic development of the rural areas.
\end{abstract}

Keywords: Small scale enterprises; poverty reduction; rural areas

\section{INTRODUCTION}

Nigeria is predominantly rural with more than $80 \%$ of the total population living in rural areas (Joseph, 2005). The economy is basically agrarian with most of the people living in squalor and poor level of living which is attributed to poverty. (Ajayi, 2009). Poverty has diverse economic on social dimensions that express its manifestation in lack of income and insufficient productive resources to ensure sustainable livelihood. Poverty indicators include: hunger and malnutrition, or lack of access to quality education and basic services, increased molidity and mortality which occur as a result of illness in adequate housing homelessness, unsafe environment and social dissemination. As a matter of fact the concept of poverty does not subject itself to any straight Jacket definition (Agumagu, 2000), all these indicators are the attribute of poverty in the rural areas of Sokoto state.

Since mid-seventies, successive governments in Nigeria have come up with a lot of laudable initiatives or programmes geared toward poverty alleviation (Idachaba, 2006). Such programmes include, Operation Feed the Nation (OFN) 1976, the Green Revolution (GR) 1980, The Structural AdjustmentProgramme (SAP) 1986, Family Economic Advancement Programme (FEAP) 1993, and National Poverty Eradication Programme (NAPEP) 2000. The National Poverty Eradication Programme (NAPEP), which has it main objectives to improve 
the socio economic welfare of rural people, with a properly structured organizational frame work for its achievement is an offshoot of poverty alleviation programme (PAP) and it was established in 2001 (Aliu, 2001 Joseph, 2005; Gumwa, 2009).

Similarly, in 2007 Sokoto state government launched the state poverty reduction (SPORA) to run the youth skills acquisition, especially among women. It also aim to boost the agricultural sector by providing 300 tractors, 50,000 irrigation pumps and 200 rice threshing machines. The programme has so far graduated over 17,000 youth on various skills acquisition in 2012. The government recently earmarked N90, 000,000 for the purchase of 300 tricycles popularly known as Keke NAPEP as a strategy in poverty reduction.

Despite all the above programmes, little has change in the rural areas; all these failed to bring the number in absolute poverty down. This is to the fact that, most of the programmes are urban based, they are politically tailored and most benefits went to few party members, no emphasis on sustainable small scale enterprises and there is no proper coordination between the tiers of government and the targeted members (poor people).It has been observe that all the effort made were not concern with the idea of establishing small scale enterprises in order to promote economic growth and supplement income from farming activities during the dry season as well as controlling mass migration especially to the southern part of Nigeria.

\section{POVERTY: A REVIEW OF THE CONCEPT}

Although poverty is one of the most familiar and enduring conditions known to humanity, it is an extremely complicated concept to understand. Some researchers view it as a reaction to the state of being poor, whereas other perceives it as a process of adapting to the condition of poverty. Historical definition are numerous, but can be classified as relating to either lack of financial income or lower social status. Numerous factors contribute to the concept of poverty including political, economic, social and cultural forces. The one that has consistently had the greatest effect on the evolving concept is the passage of time, which encompasses all these forces in a very intricate manner.

As there are divergent views on the concept of poverty, one could observe that poverty exist when people lack the means to satisfy their basic needs. Joseph (2005) indicated that in Africa and Nigeria in particular, the colonialist imposed capitalist economic system, which allowed for exploitation and domination by the rich individuals, including exploiting the labour of others to increase their wealth. Besides, when the colonialist shifted emphasis from food crops to cash crops as deliberate governments policy in order to serve the needs of the industries in the metropolitan Europe shortage of food began to manifest amongst the rural dwellers. Hence the introduction of series of government intervention programmes from independence till date, of which National poverty eradication programme is one, were all geared towards mitigating the effect of poverty on the livelihood of its citizenry.

The implication of poverty in rural areas of Sokoto has to do with high level of illiteracy, poor access to portable drinking water, absence of modern agricultural facilities, availability of hunger, unqualified medical doctors, poor representation and freedom at local, state and federal government level, poor job opportunities and mass migration across the country. 


\section{NATURE AND CHALLENGES OF POVERTY IN SOKOTO STATE}

Poverty in state like Borno, Yobe, Jigawa, Sokoto is chronic and pervasive. It is generally believed that the current spate of violence being perpetrated by insurgents in some parts of the North could be attributed to poverty and human deprivation (This day, 2013).

The National Bureau of statistics (NBS) released its figures February 2013, showing Sokoto state as having the highest incidence of poverty, when compared to other states in the country. (Punch, 2013; This day, 2013).

Sokoto State Government in its determination to actualize the eight millennium development goals partnered with the MDG's office in the state towards eradicating extreme hunger and poverty that manifest in material deprivation, limited access to capabilities that could facilitate long and healthy life, good education, standard of living as well as meaningful participation in decision affecting individual life.

It was in view of the high level of poverty in the rural communities of Sokoto state coupled with mass unemployment among the youth, the present government had in the last five years attempted to empower over 30,000 youths and women in all the 23 local government areas of the state. The youths and women were trained in various vocational skills to enable them start up a business and able to support their families there by reducing poverty. However, despite the laudable initiatives of the government, not much impact was recorded in terms of tackling mass poverty affecting the people. Analyst suggests that the obstacles have to do with corruption and political interference.

\section{1. Concept of Small Scale Business}

Defining small scale enterprises is a difficult task because the definition of small scale industries varies from country to country and from one time to the other in the same country depending upon the pattern and stage of development. A small and medium enterprises in Nigeria is defined as any enterprises with a maximum asset of base of $\$ 500$ million (including land and working capital) and with no lower or upper limit of staff. Delhi, 2004 for the first time defined small scale industry as one which is operated mainly with hired labour usually 05-50 hands. Also in the context of Sokoto, some small scale industries may start from one or more staff to 50 staff (e.g. Black smith, bakery, dying and hand craft).

These small businesses have continued to contribute toward the development of Sokoto town since before independence to date, due to absence of large scale industries in the region. They play an important role in employment creation, resource utilization and income generation and have been helping to promote changes in a gradual and phased manner.

\section{2. Small Scale Business and Poverty Reduction}

Small-scale enterprise development reduces poverty. New and existing business assisted by the project (rural enterprises project in Ghana) have contributed to increased economic activity, job opportunities and poverty reduction in rural areas. The performance and impact of the projects technology and business skills training and counseling programmes to create new business and employment demonstrate that they can be used as a model for reducing rural poverty in rural areas of Sokoto. Being a government initiative its believe that corruption and political interference may only be an obstacle to the project.

With regard to this issue, this paper try to diver the idea in encouraging the rural people to be self reliant by sourcing their fund and using the available resources and capital around them to set up a business. 


\section{3. Major Challenges in Small Business in Rural Areas}

Small scale business available in Sokoto town are very low in nature, this is because most of the people engage are not well trained and skills, secondly the problem of capital is very serious hence the believe of the people will not allowed them to have access to bank loan, and the government assistance is usually political. Government has initiated laudable policies to support the small scale business sectors in the Nigerian economy. But they still exists, some problems have limited their access to capital and other services for which government policies are specifically meant to solve some of these problems include poor management, high rates of business failure, low productivity, under capitalization poor accounting standards shortage of still indiscipline.

\section{4. Source of Fund}

Personal savings should be the major source of finance for the entrepreneurs. This is accelerated savings earned by him as an employee elsewhere or inherited. The proprietor of the small firms may perhaps supplements his personal savings with loans from friend and relations contribution within friends and relation may also be included to this effect, the small-scale industry division of the federal ministry of industries was established to imitate and implement Nigeria and promotion of small year. The industrial development centre (IDCs) were established to provide technical support and man power training.

\section{5. Some Small Business ideas for Small Towns}

There are still various ways for the rural dwellers to make money in such places; starting a business in a small town has its upsides, firstly, smaller capital and lower overhead is required to start business. And secondly, it's easier to organize a business in a small town where people know each other. It's a known fact that the economy of rural areas is not as buoyant as urban areas yet, some die hard individuals are still running profitable businesses from such rural areas. The following are the suggested business, available in rural areas.

- Production of Organic Product

- Construction

- Modern Poultry Keeping

- Vending Buffalo Milk

- Vegetable Garden Farm

- Writing Studio

- Become a Local Goods Retailer

- Sell Global Product

- Local Clothing

- Baking Industry

\section{Other opportunities include:}

i. Florist

ii. Laundry services

iii. Firewood delivery

iv. Sharing the knowledge

v. Local jewelry

vi. Sell fixed items 
Because the need for development is as great as ever, but future development cannot simply follow the model of the past. This is true for the developing countries and every community in the world. In the past economic activity tended to mean wasteful use of resources and pollution. We need to find a way forward. This is the challenge of sustainable development. That we need to find ways to achieve economic growth and the reduce poverty and environmental objectives of the same time.

The role that the above opportunities may play in reducing poverty include among others, Job creation, economic growth and development of the area through revenue generation, controlling mass migration, promote literacy level and provide freedom as well as self-reliant

\section{CONCLUSION}

This paper shown that there are so many lucrative business you can start small in rural areas and yet make it big and interesting as well as running away from poverty and increasing the economic growth of your locality. Staying in rural areas is no reason why you will not be able to succeed if you want to. All you just need is a determined mined set and a good business strategy. It has shown that corruption and political interference are the detrimental factor of achieving the goal of National poverty Eradication programme (NAPEP).

The paper thoroughly touches the challenges by poverty and the ways of tackling the challenges by improving small scale business;

\section{Suggestion}

In view of the above, the paper suggests the following;

- The need for the government to empower the efficiency of poverty reduction agencies with a view to fight corruption and promote the integrity and accountability with the institutions.

- There is need for an effective and efficient enlightenment and awareness campaign in the rural areas on the importance of small scale enterprises as a tool of becoming selfreliant and improve standard of living.

- Improving the level of literacy in the rural areas in accepting bank loan and avoid the wrong perception that loan posed a threat to their future.

- Promoting the efficiency of basic human needs, infrastructural facilities and social amenities such as good roads in order to ease the transport.

- There should be well equipped acquisition centers in every local government area of Sokoto State in order to enhance the training of youths, by engaging them in skills like weaving, carpentry in reducing the rate of unemployment.

- In the implementation of the millennium development goals (MDG's) emphasis should be given to community empowerment of boosting the small scale business

- Community empowerment efforts leading to poverty reduction should be based on community driven development (CDD) in which rural individuals will be involve in decision making on matters affecting them so as to have accurate sustainable development. 


\section{References}

[1] Ajayi, A.R. (2009). The Role Expectation Agricultural Extension in Poverty Alleviation in a Democratize and Deregulated Economy in: Perspective in Agricultural Extension and Rural Development, J.U Agbamu (ed). Sprinfield Publisher Ltd, Lagos.

[2] Agumugu, A.C (2000). Poverty Alleviation in Nigeria: Can Agricultural Extension Help? In: Agbamu, J.U (ed) (2009); Perspective in Agricultural Extension and Rural Development, springfield publishers Ltd, Lagos; Pp. 345.

[3] Aliyu, A. (2001). Natural Poverty Eradication Programme (NAPEP): Completion, Implementation Co-ordination and Monitoring. In Joseph 1.0 (2005). An Assessment of Impacts of Poverty Reduction Programme in Nigeria as a Development Strategy, Ph.D Dissertation of St Clement, University of Truks and Caicoos, Island.

[4] Delhi (2004). The Role of Small Scale Business in India.Linkedin Co-corporation (C) 2004. Also Available at www.slideshare.net/ karampanach.

[5] Gummwa, G. (2002). Kogi State National Poverty Eradication programme (NAPEP): The Story So Far. Poverty Monitoring Mammal of Kogi State Napep, pp. 1-19.

[6] Idachaba, F.S (1988). The Green Revolution: Goals for and Constraints on Agricultural Development in the 1980s in: Ijere, M.O and F.S Idachaba (eds) ARMT Seminar Series, NDI, Ilorin, Nigeria: pp 18-36.

[7] Joseph, I.O (2005) An Assessment of Impacts of Poverty/Reduction Programme in Nigeria as a Development Strategy PhD Dissertation of St Clement University of Turks and Caicoos, Island.

[8] Ministry of Commerce (2014). Effort of Government towards poverty reduction. A speech of the commissioner of commerce during the graduation ceremony of skill acquisition training programme in Sokoto state.

[9] National Poverty Eradication Programme (NAPEP) (2001). Conception, Implementation and Monitoring, FGN.

[10] Punch (2013). Sokoto, Katsina Top List of Poor States 6 Jan. 2013 Retrieved 10/04/14

[11] This day (2013). Sokoto State the Poorest State in Nigeria 7 Jan 2013. Also Available at: www.Thisday line.com.

[12] World Bank (2008). Understanding Poverty Web, World Bank.org retrieved 2014-03-24.

[13] Jacek Tittenbrun, International Letters of Social and Humanistic Sciences 2 (2014) 20-40.

[14] Pawa Tersoo, International Letters of Social and Humanistic Sciences 3 (2014) 26-36.

[15] Rabi'u Muhammad Ishaq, International Letters of Social and Humanistic Sciences 3 (2014) 37-44.

[16] Kabiru Ibrahim Yankuzo, International Letters of Social and Humanistic Sciences 4 (2014) 1-8.

[17] Uloma Charity Oguzor, International Letters of Social and Humanistic Sciences 4 (2014) 97-104. 
[18] Okezie A. Ihugba, Bankoli Bankong, N. C. Ebomuche, International Letters of Social and Humanistic Sciences 5 (2014) 92-113.

[19] Halima Sidi Bamall, International Letters of Social and Humanistic Sciences 8(1) (2014) 50-55.

[20] Aliyu Mus, International Letters of Social and Humanistic Sciences 8(1) (2014) 56-65.

[21] Chagbe Kurayemen, Gyata B. A, Ali Emmanuel, International Letters of Social and Humanistic Sciences 8(1) (2014) 82-89.

[22] Nneka Rita Udoye, Victor Etim Ndum, International Letters of Social and Humanistic Sciences 8(2) (2014) 130-139.

[23] Amos N. Dombin, International Letters of Social and Humanistic Sciences 8(2) (2014) 148-157.

[24] Juliana A. Oboniye, International Letters of Social and Humanistic Sciences 8(2) (2014) 158-169.

[25] Adebowale Adeyemi-Suenu, International Letters of Social and Humanistic Sciences 13 (2014) 89-94.

[26] Olanrewaju Abdul Shitta-Bey, International Letters of Social and Humanistic Sciences 15(1) (2014) 14-21.

[27] Ioan Constantin Dima, Janusz Grabara, Vladimir Modrak, International Letters of Social and Humanistic Sciences 15(2) (2014) 148-156.

[28] Nirmal Kumar Betchoo, International Letters of Social and Humanistic Sciences 16(1) (2014) 39-48.

[29] Ioan Constantin Dima, Alina Tुenescu, Petre Bosun, International Letters of Social and Humanistic Sciences 16(1) (2014) 75-85. 